\title{
Jurist-Diction
}

Volume 2 No. 5, September 2019

Histori artikel: Submit 1 Agustus 2019; Diterima 8 Agustus 2019; Diterbitkan online 1 September 2019.

\section{Kepailitan Terhadap Induk Perusahaan Yang Menjamin Utang Yang Diberikan Kepada Anak Perusahaan (Kajian Yuridis terhadap Putusan Nomor 05/Pailit/1998/ PN.Niaga/Jkt. Pst )}

\author{
Andrew Ade Nugraha \\ adekandrew@gmail.com \\ Universitas Airlangga
}

\begin{abstract}
Humans as social beings function to give and take advantage of each other, who make connections to meet their needs. One form of this relationship is to conduct business activities, both buying and selling, leasing and debts. An example is establishing a Business Entity, even if its business activities are growing, the company can expand its wings by forming a Subsidiary. The establishment of a Business Entity that is so easy has caused many Business Entities to go bankrupt because of financial related problems. The company's financial problems often involve the Bank to get additional funds. Provision of funds from the Bank as a creditor to the company as a debtor is written in an agreement, namely in the form of a credit agreement (credit loan). However, if the Company is unable to pay the debt at a predetermined time (breach the contract), the Bank may submit a Bankruptcy Application. A further problem is that if the parent company that is declared bankrupt has a subsidiary, is the share held by the parent to the subsidiary a bankrupt asset? Bankruptcy applications submitted by creditors aim to get repayments of debts held by the Debtor.
\end{abstract}

Keywords: Bankruptcy; Holding Company; Subsidiary Company; Creditor; Debtor.

\begin{abstract}
Abstrak
Manusia sebagai mahkluk sosial berfungsi untuk saling memberi dan mengambil manfaat, yang melakukan hubungan untuk memenuhi kebutuhan hidupnya. Salah satu bentuk hubungan tersebut adalah dengan melakukan kegiatan bisnis, baik jual-beli, sewa-menyewa maupun utang-piutang. Contohnya adalah dengan mendirikan Badan Usaha, bahkan apabila kegiatan bisnisnya semakin berkembang maka perusahaan tersebut dapat melebarkan sayapnya dengan membentuk Anak Perusahaan. Pendirian Badan Usaha yang begitu mudah, menyebabkan banyak Badan Usaha yang mengalami pailit karena permasalahan yang berkaitan dengan keuangan (financial). Permasalahan keuangan perusahaan seringkali melibatkan pihak Bank untuk mendapatkan tambahan dana. Pemberian dana dari Bank sebagai Kreditor kepada perusahaan sebagai Debitor dituliskan dalam sebuah perjanjian, yaitu berupa perjanjian kredit (pinjaman kredit). Namun apabila Perusahaan tersebut tidak mampu membayar utang pada waktu yang sudah ditentukan (wanprestasi), maka Bank dapat mengajukan Permohonan Pailit. Permasalahan selanjutnya adalah apabila induk perusahaan yang dinyatakan pailit tersebut memiliki anak perusahaan, apakah saham yang dimiliki oleh induk kepada anak perusahaan merupakan harta pailit? Permohonan pailit yang diajukan oleh para Kreditor bertujuan untuk mendapatkan pelunasan utang-utang yang dimiliki Debitor.
\end{abstract}

Kata Kunci:Kepailitan; Induk Perushaan; Anak Perusahaan; Kreditor; Debitor.

\section{Pendahuluan}

Pada perkembangan masa modern membawa dampak tidak hanya sebatas kebutuhan primer namun juga terhadap di bidang sosial, ekonomi, budaya, dan lain-lain. 
memenuhi kebutuhan hidup tersebut tidak dapat diperoleh secara individu. Sebagai makhluk sosial, manusia berfungsi untuk saling memberi dan mengambil manfaat, maka manusia sebagai makhluk sosial merupakan mahkluk yang berhubungan untuk memenuhi kebutuhan hidupnya. Namun terkadang kebutuhan masyarakat tidak diperoleh dari hanya satu tempat saja, melainkan dengan berbagai macam bisnis yang diperlukan sebagai alat untuk melakukan proses pemenuhan kebutuhan agar keberlangsungannya tetap terpenuhi.

Dengan berbagai macam bisnis yang diperlukan sebagai alat untuk melakukan proses pemenuhan kebutuhan agar kehidupannya menjadi lebih sejahtera yaitu mendirikan suatu badan usaha. Dalam mendirikan suatu badan usaha sangatlah mudah. Suatu usaha tidak selalu dilakukan dengan pihak lain, tetapi dapat merupakan perusahaan perorangan. Begitu mudahnya membuat badan usaha berbadan hukum ataupun bukan badan hukum tidak sepenuhnya baik, disebabkan dalam perjalanan usahanya dapat mengalami permasalahan yang akan timbul. Contohnya adalah masalah keuangan yang mengakibatkan pailit. Selama debitor belum dinyatakan pailit oleh pengadilan, selama itu pula debitur masih dianggap mampu membayar utang-utangnya yang telah jatuh tempo. Sedangkan kepailitan dalam pasal 1 angka 1 Undang-Undang Nomor 37 Tahun 2004 tentang Kepailitan dan Penundaan Kewajiban Membayar Utang (yang selanjutnya disebut UUK-PKPU), kepailitan adalah Sita Umum atas semua kekayaan Debitor Pailit yang pengurusan dan pemberesannya dilakukan oleh Kurator di bawah pengawasan Hakim Pengawas sebagaimana diatur dalam Undang-Undang ini.

Untuk dapat dinyatakan pailit, seorang debitor harus memenuhi syarat-syarat sebagai berikut: ${ }^{1}$

a. Debitor mempunyai dua atau lebih kreditor;

b. Tidak membayar sedikitnya satu utang jatuh waktu dan dapat ditagih;

c. Atas permohonannya sendiri maupun atas permintaan seorang atau lebih kreditornya.

${ }^{1}$ Rahayu Hartini, Penyelesaian Sengketa Kepailitan di Indonesia Dualisme Kewenangan Pengadilan Niaga \& Lembaga Arbitrase (Kencana 2009).[9]. 
Berdasarkan Pasal 1 angka 2 Undang-Undang Nomor 7 Tahun 1992 tentang Perbankan sebagaimana diubah dengan Undang-undang nomor 10 Tahun 1998, Bank merupakan badan usaha yang menghimpun dana dari masyarakat dalam bentuk kredit dan atau bentuk-bentuk lainnya dalam rangka meningkatkan taraf hidup rakyat banyak. Dari segi ini bahwa perbankan di indonesia memiliki fungsi utama yaitu menghimpun dana dari mayarakat dan memberikan kredit kepada masyarakat demi menunjang pertumbuhan ekonomi untuk mensejahterakan hidup rakyat banyak. Bank berperan sebagai agent of intermediary, dengan menyelenggarakan fungsi-fungsi sebagai berikut: ${ }^{2}$

1. Fungsi menghimpun dana;

2. Fungsi pemberian kredit;

3. Fungsi memperlancar lalu lintas pembayaran;

4. Fungsi sebagai penyedia informasi, pemberian konsultasi dan bantuan penyelenggaraan administrasi.

Pemberian kredit pada umumnya dilakukan dengan mengadakan suatu perjanjian. Perjanjian tersebut terdiri dari perjanjian pokok yaitu perjanjian utang piutang dan diikuti dengan perjanjian tambahan berupa perjanjian pemberian jaminan oleh pihak debitor. Setiap kredit yang telah disetujui dan disepakati antara pemberi kredit dan penerima kredit wajib dituangkan dalam bentuk perjanjian yaitu perjanjian kredit. $^{3}$

Dalam mengembangkan pemasaran suatu perusahaan, dapat dilakukan dengan cara membuat cabang atau anak perusahaan. Adakalanya usaha dari suatu perusahaan yang sudah besar sehingga perusahaan tersebut perlu dipecah menurut penggolongan usahanya. Akan tetapi kebutuhan pula agar usaha yang telah dipecah- pecah tersebut yang masing-masing akan menjadi Perseroan Terbatas (PT) yang mandiri dan dalam kepemilikan yang sama, beroperasi dengan adanya pengontrol yang masih tersentralisasi dalam batas-batas tertentu. Pecahan-pecahan perusahaan bersama-sama dengan perusahaan-perusahaan lain yang mungkin telah terlebih dahulu ada dengan pemilik yang sama atau minimal

\footnotetext{
${ }^{2}$ Andy Hartanto, Hukum Jaminan dan Kepailitan (Laksbang Justitia 2015).[13].

${ }^{3}$ Munir Fuady, Hukum Perkreditan Kontemporer (Citra Aditya Bakti 2003).[32].
} 
ada hubungan khusus, dimiliki dan dikomandoi oleh suatu perusahaan mandiri pula, perusahaan pemilik (pengomando) disebut dengan holding company, parent company atau controlling company. ${ }^{4}$

Pengaturan hukum untuk kegiatan bisnis salah satunya diatur dalam Undang-Undang Nomor 40 Tahun 2007 tentang Perseroan Terbatas (UU PT). Pasal 7 ayat (1) UU PT mengizinkan kepada seseorang untuk mendirikan suatu perseroan. Keterkaitan antara dua perseroan melalui kepemilikan saham ini menjadi alasan keberadaan bagi lahirnya keterkaitan antara induk dan anak perusahaan, baik melalui pendirian perseroan, pengambil alihan saham, pemisahan usaha, maupun joint venture. ${ }^{5}$

Sebelum mengemukakan pendapat, Majelis Hakim Niaga telah mengetahui bahwa selain diajukannya permohonan pailit terhadap PT. OC ini, Kreditur telah pula mengajukan permohonan pailit secara terpisah terhadap PT. OMA di bawah permohonan pendaftaran No.04/Pailit/PN.NIAGA/Jakarta Pusat (Perkara No.04/1998), yang pada saat perkara ini diajukan permohonan PKPU sementara dari PT. OMA telah dikabulkan. Atas dasar itu, Majelis Hakim Niaga berkesimpulan bahwa permohonan kepailitan yang diajukan terhadap sebuah induk perusahaan (holding company) seharusnya diajukan dalam satu permohonan dengan permohonan kepailitan terhadap anak perusahaannya (subsidiaries). Hal itu didasarkan pada pertimbangan bahwa substansi perkara ini terkait erat dengan substansi yang diajukan oleh Kreditur terhadap PT. OMA dalam Perkara No.04/1998. Yaitu berdasarkan 2 (dua) Perjanjian Kredit yang sama. Dengan demikian, pengajuan permohonan kepailitan terhadap induk dan anak perusahaan secara terpisah tentunya akan membawa konsekuensi yuridis yang membingungkan (rancu).

\footnotetext{
${ }^{4}$ Munir Fuady, Hukum Perusahaan Dalam Paradigma Hukum Bisnis (Citra Aditya Bakti 2008).[9].

5 Sulistiowati, Tanggung Jawab Hukum Pada Perusahaan Grup Di Indonesia (Erlangga 2013).[20].
} 


\section{Permohonan Pailit Terhadap Induk Perusahaan yang Menjamin Utang Anak Perusahaan}

Perusahaan grup merupakan gabungan atau susunan perusahaan-perusahaan yang secara yuridis mandiri, yang satu sama lain terkait begitu erat sehingga membentuk suatu kesatuan ekonomi yang tunduk kepada suatu pimpinan perusahaan induk sebagai pimpinan sentral. ${ }^{6}$ Perusahaan grup biasanya terjadi dikarenakan suatu perusahaan melebarkan sayapnya dengan membentuk anak-anak perseroan untuk suatu usaha tertentu. Suatu perusahaan grup pada umumnya terdiri dari perusahaan induk dan satu atau beberapa perusahaan anak. Pada dasarnya konsep Holding Company dalam proses pembentukan dapat dilakukan melalui beberapa prosedur yaitu: ${ }^{7}$

1. Prosedur Residu

Dalam hal ini, perusahaan asal dipecahpecah sesuai dengan masing-masing sektor usaha. Perusahaan yang dipecah-pecah tersebut telah menjadi perusahaan yang mandiri, sementara sisanya (residu) dari perusahaan asal dikonversi menjadi perusahaan holding, yang juga memegang saham pada perusahaan pecahan tersebut dan perusahaan-perusahaan lainnya jika ada.

2. Prosedur Penuh

Prosedur penuh ini sebaiknya dilakukan jika sebelumnya tidak terlalu banyak terjadi pemecahan/pemandirian perusahaan, tetapi masing-masing perusahaan dengan kepemilikan yang sama/berhubungan saling terpencar-pencar, tanpa terkonsentrasi dalam suatu perusahaan holding. Dalam hal ini, yang menjadi perusahaan holding bukan sisa dari perusahaan asal seperti pada proses residu, tetapi perusahaan penuh dan mandiri.

\section{Prosedur Terprogram}

Adakalanya, sudah sejak semula orang-orang bisnis telah sadar akan pentingnya perusahaan holding. Sehingga awal memulai bisnis sudah terpikir untuk

${ }^{6}$ Sulistiowati, Aspek Hukum Dan Realitas Bisnis Perusahaan Grup Di Indonesia (Erlangga 2010).[20].

${ }^{7}$ Munir Fuady, Op.Cit.[84-89]. 
membentuk suatu perusahaan holding. Karenanya, perusahaan yang pertama sekali didirikan dalam grupnya adalah perusahaan holding. Kemudian untuk setiap bisnis yang dilakukan, akan dibentuk atau diakuisisi perusahaan lain, dimana perusahaan holding sebagai pemegang saham biasanya bersama-sama dengan pihak lain sebagai partner bisnis. Demikianlah, maka jumlah perusahaan baru sebagai anak perusahaan dapat terus berkembang jumlahnya seirama dengan perkembangan bisnis dari grup usaha yang bersangkutan.

Seperti yang telah dijelaskan sebelumnya bahwa dalam perusahaan grup (holding company) terdapat induk perusahaan dan anak perusahaan. Menurut Penjelasan Pasal 29 Undang-Undang No. 1 Tahun 1995 (UUPT sebelum UndangUndang No. 40 Tahun 2007) yang dimaksud dengan anak perusahaan adalah perseroan yang mempunyai hubungan khusus dengan perseroan lainnya yang terjadi karena: ${ }^{8}$

a. lebih dari 50\% (lima puluh persen) sahamnya dimiliki oleh perusahaan induknya;

b. lebih dari 50\% (lima puluh persen) suara dalam RUPS dikuasai oleh perusahaan induknya;

c. kontrol atas jalannya perseroan, pengangkatan, dan pemberhentian direksi dan komisaris sangat dipengaruhi oleh perusahaan induknya.

\section{Syarat-Syarat Permohonan Pailit}

Syarat-syarat pailit ini untuk mengindarkan para Kreditor berebutan saling mendahului untuk menguasai dan menjual harta (aset) Debitor sehingga timbul ketidakadilan pembagian harta (aset) Debitor,maka hukum membuat Undangundang Kepailitan. Tujuan-tujuan utama dari hukum kepailitan (bangkruptcy law) berdasarkan Pasal 1 ayat (1) UUK-PKPU, kepailitan adalah sita umum atas semua kekayaan Debitor Pailit yang pengurusan dan pemberesannya dilakukan olah Kurator di bawah pengawasan Hakim Pengawas sebagaimana diatur dalam

\footnotetext{
${ }^{8}$ M. Yahya Harahap, Hukum Perseroan Terbatas (Sinar Grafika 2013).[52].
} 
undang-undang ini Syarat-syarat permohonan pailit dinyatakan pada Pasal 2 ayat (1) UUK-PKPU, yaitu debitor yang mempunyai dua atau lebih kreditor dan tidak membayar lunas setidaknya satu utang yang telah jatuh waktu dan dapat ditagih, dinyatakan pailit dengan putusan pengadilan, baik atas permohonan satu atau lebih kreditornya. Jadi jika mempailitkan debitor harus:

1. Mempunyai 2 (dua) atau lebih kreditor

Syarat ini menegaskan bahwa dalam kepailitan dihindari sita individual, karena jika hanya terdapat 1 kreditor, maka tidak akan sesuai dengan eksistensi hukum kepailitan yang mengatur bagaimana cara membagi harta kekayaan debitor di antara para kreditornya ;

2. Tidak membayar lunas setidaknya satu utang yang telah jatuh tempo dan dapat ditagih

Syarat-syarat pailit ini untuk mengindarkan para Kreditor berebutan saling mendahului untuk menuasai dan menjual harta (aset) Debitor sehingga timbul ketidakadilan pembagian harta (aset) Debitor, maka hukum membuat Undangundang Kepailitan. Berikut ini tujuan-tujuan utama dari hukum kepailitan (bangkruptcy law), antara lain:

1. Memberi kesempatan kepada Debitor untuk berunding dengan para kreditornya untuk melakukan restrukrisasi utang;

2. Melindungi para Kreditor konkuren untuk memperoleh hak mereka sehubungan dengan berlakunya asas jaminan, bahwa "semua harta kekayaan Debitor baik yang bergerak maupun tidak bergerak, baik yang ada maupun yang akan ada dikemudian hari, menjadi jaminan bagi perikatan Debitor;

3. Menjamin agar pembagian harta Debitor di antara para Kreditor sesuai dengan asas pari passu (membagi secara proposional harta kekayaan Debitor kepada para Kreditor konkuren berdasarjab perimbangan besarnya tagihan masingmasing);

4. Memastikan siapa saja Kreditor yang memiliki tagihan piutang terhadap Debitor pailit;

5. Memastikan kebenaran jumlah piutang dengan melakukan verifikasi;

6. Memberikan perlindungan kepada Debitor yang beritikad baik agar penagihan piutang Kreditor tidak langsung dilakukan terhadap para Debitor tetap melalui likuidator atau kurator setelah Debitor dinyatakan pailit oleh pengadilan;

7. Melindungi para Kreditor dan Debitor yang hanyha menguntungakan Kreditor tertentu;

8. Melindungi para Kreditor dari sesama Kreditor;

9. Mencegah agar Debitor tidak melakukan perbuatan-perbuatan yang dapat merugikan kepentingan para Kreditor; 
10. Menegakkan ketentuan action pauliana, yaitu hak yang diberikan oleh undangundang kepada setiap Kreditor untuk menuntut kebatalan dari segala tindakan Debitor yang tidak diwajibkan untuk dilakukannya;

11.Menghukum pengurus perusahaan yang karena kesalaahannya telah mengakibatkan perusahaan mengalami keadan keuangan yang buruk;

\section{Permohonan Pailit terhadap Induk Perusahaan selaku Penanggung Hutang}

Perjanjian jaminan (penanggungan) diatur dalam Pasal 1820 BW dimana dikatakan penanggungan ialah suatu persetujuan di mana pihak ketiga demi kepentingan kreditor, mengikatkan diri untuk memenuhi perikatan debitor, bila debitor itu tidak memenuhi perikatannya. Mengenai penanggungan (borgtocht) bahwa tujuan dan isi dari penanggungan ialah memberikan jaminan untuk dipenuhinya perutangan dalam perjanjian pokok. Adanya penanggungan itu dikaitkan dengan perjanjian pokok, mengabdi pada perjanjian pokok. Maka dapat disimpulkan bahwa perjanjian penanggungan itu bersifat accesoir. ${ }^{9}$

Sedangkan ditinjau dari sifat jaminan penanggungan,bahwa jaminan penanggungan tergolong jaminan yang bersifat perorangan, yaitu adanya orang pihak ketiga yang menjamin memenuhi perutangan manakala debitor wanprestasi. Pada jaminan yang bersifat perorangan, pemenuhan prestasi hanya dapat dipertahankan terhadap orang-orang tertentu, yaitu si debitor atau penanggungnya. ${ }^{10}$

Rangkaian perbuatan hukum dari dibuatnya perjanjian pejaminan memliki beberapa tahap yaitu:

1. Tahap pertama berupa penandatanganan Perjanjian Kredit

Tahap pertama didahului dengan dibuatnya perjanjian pokok yang berupa perjanjian kredit antara pemberi kredit (Kreditor) dan peminjam Kredit (Debitor). Bentuk perjanjian kredit ini bebas karena Undang-undang tidak menentukan bentuk tertentu. Di dahuluinya perjanjian pokok yang berupa perjanjian kredit ini sesuai sifat accessoir dari perjanjian penjaminan

${ }^{9}$ Sri Soedewi, Hukum Jaminan di Indonesia Pokok-Pokok Hukum Jaminan dan Jaminan Perorangan (Liberty 2011).[81].

${ }^{10}$ Sri Soedewi, Ibid.[83]. 
(Borgtoch).

2. Tahap kedua berupa penandatanganan Akta Borgtocht (perjanjian penanggungan) Setelah tahap pertama berupa pembuatan perjanjian selesai, maka dilanjutkan dengan tahan kedua yang berupa pembuatan perjanjian penjaminan antara kreditor dengan pihak ketiga yang mengikatkan diri sebagai penjamin hutang. Yang dimaksud pihak ketiga dalam hal ini adalah siapa saja (Bukan Debitor) yang memenuhi syarat hukum dan bersedia untuk mengikatkan diri sebagai penjamin, biasanya orang atau corporate yang memiiki hubungan dan kepentingan bisnis dengan debitornya. Hubungan tersebut bisa seperti hubungan keluarga, teman atau hubungan bisnis. Dan sering kali pihak ketiga tersebut memiliki tujuan atau motif ekonomi untuk memajukan perusahaan yang dimiliki. ${ }^{11}$

Perusahaan induk sebagai pemegang saham dari anak perusahaan memiliki posisi ekonomi dan peran berbeda dengan pemegang saham individu dalam sebuah PT. Dalam perusahaan grup, induk perusahaan memiliki dualitas untuk menjadi pemegang saham anak perusahaan dan pemimpin utama perusahaan grup. Akan tetapi hukum perusahaan tidak membedakan posisi induk perusahaan dengan pemegang saham individu dalam PT tertentu. Anak perusahaan yang melakukan pengikatan atau perjanjian dengan pihak ketiga memiliki tanggung jawab untuk membayar hutang. Jika perusahaan melanggar kontrak atau tanggung jawab untuk membayar hutang pada saat jatuh tempo, anak perusahaan secara hukum dianggap default (gagal). Dalam hal ini, wanprestasi adalah tindakan dimana pihak tertentu tidak memenuhi tanggung jawab sebagaimana dinyatakan dalam perjanjian yang sebelumnya ditetapkan antara kreditor dan debitor.

Jika perusahaan induk bertindak sebagai penjamin dari anak perusahaan yang pailit, penjamin memiliki tanggung jawab menjamin pembayaran kembali hutang dari debitor ke kreditor berdasarkan Pasal 1820 BW. Perusahaan induk sebagai penjamin dalam perjanjian antara anak perusahaan sebagai debitor dan pihak

\footnotetext{
${ }^{11}$ Sutarno, Aspek-aspek Hukum Perkreditan pada Bank (Alfabeta 2009).[242].
} 
ketiga sebagai kreditor didasarkan pada perjanjian jaminan. Pada dasarnya, sebagai penjamin, ada hak khusus yang diberikan oleh BW, termasuk:

a. Hak memprakarsai tuntutan bahwa kekayaan debitor harus disita dan dilelang untuk membayar hutang debitor kepada kreditor, sebagaimana dinyatakan dalam Pasal $1831 \mathrm{BW}$.

b. Hak untuk melakukan pemecahan utang sebagaimana disebutkan dalam Pasal 1837 BW.

c. Hak untuk dihentikan dari penjaminan jika merupakan kesalahan kreditor bahwa penjamin dihalangi untuk melakukan subrogasi (Pasal 1848 dan 1849 BW).

d. Hak untuk mengusulkan pembelaan.

\section{Kasus Kepailitan Induk Perusahaan}

Putusan No. 04 /Pailit/1998/PN.Niaga/Jkt.Pst jo No. 03/Pailit/1998/ PN.Niaga American Express Bank Ltd, Singapura et.al. (bersama-sama: Kreditor) mengajukan permohonan pailit terhadap PT. OMA, karena PT. OMA tidak membayar hutangnya yang jatuh tempo dan dapat ditagih berdasarkan perjanjian kredit atau fasilitas pinjaman antara PT. OMA dan masing-masing Kreditor. Alasan utama terjadinya kegagalan pembayaran adalah jatuhnya nilai kurs mata uang Rupiah terhadap US Dollar. Sehingga terjadi ketidakseimbangan alur kas dalam PT. OMA, dimana debitor (nasabah) PT. OMA, yaitu yang menerima fasilitas sewa guna usaha anjak piutang, pembiayaan konsumen atau kartu kredit darinya dan merupakan perusahaan menengah, membayar hutangnya kepada PT. OMA dalam Rupiah, sedangkan hutang PT. OMA kepada masing-masing Kreditor adalah dalam US Dollar. Di atas semua itu, kesulitan alur kas PT. OMA itu semakin nyata mengingat bahwa pinjaman dalam Rupiah yang diberikan PT. OMA berasal dari dan hasil konversi dari pinjaman dalam US Dollar yang diberikan oleh masing-masing Kreditor untuk modal kerja. Pertimbangan hukum Majelis Hakim Pengadilan Niaga Permohonan PKPU sementara dikabulkan. PT. OMA selanjutnya mengajukan permohonan PKPU dengan alasan bahwa ia masih mempunyai kemampuan material untuk membayar hutangnya itu. Rencana perdamaian akan diberikan segera oleh PT. OMA. Majelis Hakim Niaga berpendapat bahwa atas dasar alat bukti yang ada PT. OMA memang masih 
mempunyai kemampuan material untuk membayar hutangnya kepada masingmasing Kreditor.

Pertimbangan Majelis Hakim Niaga Permohonan pailit tidak dapat diterima. Menimbang, bahwa subtansi atau dasar-dasar hukum Permohonan Pernyataan pailit terhadap OMA Perkara No.04 adalah sama dengan Subtansi dalam perkara Perkara No.05 bahwa dengan mencermati bukti-bukti yang diserahkan para pemohon terutama Bukti P-1 dan Bukti P-5 jo P-15, Majelis Hakim sampai pada kesimpulan, bahwa seharusnya para pemohon hanya mengajukan satu permohonan pernyataan pailit yaitu terhadap PT.OMA sekaligus terhadap PT.OC, dimana PT.OC terikat demi hukum sebagai penjamin tanggung menanggung/renteng (bahkan dianggap sebagai satu-satunya debitor utama. sehingga baik PT.OMA maupun PT.OC dapat dinyatakan pailit dalam Satu Putusan yang berlanjut dengan diumumkan secara bersama-sama dalam (sekurang-kurangnya) 2 surat kabar dan bersama-sama dalam Satu Berita Negara sesuai Pasal 13 ayat (5) UUK-PKPU

Syarat pailit yaitu Debitor yang sekalipun hanya mempunyai seorang Kreditor dapat dinyatakan pailit oleh pengadilan, baik atas permintaan Debitor sendiri maupun atas permintaan Kreditornya sepanjang Debitor tidak mampu membayar utangnya dan berada dalam keadaan berhenti membayar utangnya (insolvent) yang dapat diketahui bahwa hanya Debitor yang insolven yang dapat dipailitkan. Keadaan insolven merupakan syarat mutlak yang harus ada pada syarat-syarat kepailitan yang ditentukan oleh undang-undang. Disini PT. OMA selanjutnya mengajukan permohonan PKPU dengan alasan bahwa ia masih mempunyai kemampuan material untuk membayar hutangnya itu. Rencana perdamaian akan diberikan segera oleh PT. OMA. Majelis Hakim Niaga berpendapat bahwa atas dasar alat bukti yang ada PT. OMA memang masih mempunyai kemampuan material untuk membayar hutangnya kepada masing-masing Kreditor. PT.OC selaku induk perusahaan bertindak sebagai penjamin dari hutang dari PT.OMA selaku anak perusahaan dan karenanya merupakan debitor satu-satunya dari seluruh kreditor. Seperti yang dijelakan sebelumnya, bahwa PT.OC adalah penanggung dan bertanggung jawab atas tindakan yang dilakukan oleh PT.OMA. 
Kreditor telah pula mengajukan permohonan pailit secara terpisah dari PT. OMA dibawah permohonan Perkara No.04 bahwa permohonan kepailitan yang diajukan kepada induk perusahaan. Kemudian putusan No.03/Pailit/1998/ PN.Niaga/Jkt.Pst) menyatakan kreditor menuntut PT.OC sebagai anak perusahaan . Pengadilan Niaga menyatakan bahwa permohonan seharusnya mengajukan satu permohonan terhadap keduangnya, induk dan anak perusahaan pada waktu yang sama sehingga memungkinkan Pengadilan Niaga untuk mengangkat seorang kurator dan seorang hakim pengawas dalam satu putusan. Analisis dalam Perkara No.05 ini syarat-syarat untuk diajukan pailit harus memenuhi terpenuhi berdasarkan Pasal 2 ayat (1) jo. Pasal 8 ayat (4) UUK-PKPU.

\section{Akibat Hukum Kepailitan}

Setelah pernyataan pailit dijatuhkan, mengakibatkan harta kekayaan debitor sejak putusan pengadilan dikeluarkan dan dimasukkan kedalam harta pailit (bodel pailit) dan selanjutnya dibereskan dan dibagi kepada kreditor oleh kurator. Berdasarkan Pasal 21 UUK-PKPU Kepailitan meliputi seluruh kekayaan Debitor pada saat putusan pernyataan pailit diucapkan serta segala sesuatu yang diperoleh selama kepailitan.

Kepailitan menyebabkan seluruh harta debitor jatuh kedalam sitaan umum dan debitor juga kehilangan haknya untuk menguasai harta kekayaannya. Adapun akibat-akibat yuridis dari putusan pailit terhadap harta kekayaan debitor maupun terhadap debitor adalah sebagai berikut antara lain :

1. Putusan pailit dapat dijalankan lebih dahulu (Serta-Merta)

Pada asasnya, putusan pailitan adalah serta-merta dan dapat dijadikan lebih dahulu meskipun terhadap putusan tersebut masih dilakukan suatu upaya hukum lebih lanjut. Apabila putusan pailit dibatalkan sebagai akibat upaya hukum tersebut maka perbuatan yang dilakukan oleh kurator tetap sah dan mengikat bagi debitor.

\section{Sitaan Umum (Public Attachment)}

Harta kekayaan debitor yang termasuk harta pailit merupakan sitaan umum berserta apa yang diperoleh selama kepailitan. Hakikat dari sitaan umum adalah 
untuk menghentikan aksi terhadap perebutan harta pailit yang bisa saja akan merugikan para kreditornya.

3. Kehilangan wewenang dalam harta kekayaan

Berdasarkan Pasal 24 ayat (1) UUK-PKPU, debitor pailit demi hukum kehilangan haknya untuk mengurus dan melaksanakan perbuatan kepemilikan terhadap harta kekayaannya yang termasuk dalam kepailitan.

4. Perikatan setelah pailit

Berdasarkan Pasal 25 UUK-PKPU, segala perikatan debitor yang terbit setelah putusan pailit tidak dapat dibayar dari harta pailit. Jika peraturan ini dilanggar maka perbuatannya tidak mengikat kekayaannya tersebut, kecuali perikatan tersebut mendatangkan keuntungan terhadap harta pailit.

5. Pembayaran piutang debitor pailit

Pembayaran piutang dari si pailit setelah adanya putusan pailit tidak boleh dibayarkan pada si pailit, jika hal tersebut terjadi maka tidak membebaskan utang tersebut. Inti ketentuan ini adalah bahwa debitor pailit demi hukum kehilangan kewenangannya terhadap harta kekayaannya.

6. Penetapan putusan pengadilan sebelumnya

Berdasarkan Pasal 31 ayat (1) dan (2) UUK-PKPU, Putusan pernyataan pailit berakibat bahwa segala penetapan pelaksanaan Pengadilan terhadap setiap bagian dari kekayaan Debitor yang telah dimulai sebelum kepailitan, harus dihentikan seketika dan sejak itu tidak ada suatu putusan yang dapat dilaksanakan termasuk atau juga dengan menyandera Debitor.

7. Hubungan kerja dengan para pekerja perusahaan pailit

Berdasarkan Pasal 39 ayat (1) UUK-PKPU Pekerja yang bekerja pada Debitor dapat memutuskan hubungan kerja, dan sebaliknya Kurator dapat memberhentikannya dengan mengindahkan jangka waktu menurut persetujuan atau ketentuan perundang-undangan yang berlaku.

8. Kreditor separatis dan penangguhan hak (stay)

Berdasarkan Pasal 55 ayat (1) UUK-PKPU, setiap Kreditor pemegang gadai, jaminan fidusia, hak tanggungan, hipotek, atau hak agunan atas kebendaan lainnya, 
dapat mengeksekusi haknya seolah-olah tidak terjadi kepailitan.

9.Organ-organ PT

Berdasarkan Pasal 79 ayat (3) UU PT dan Pasal 96 UU PT, terhadap debitor pailit, direktur, dan komisaris dari suatu PT yang dinyatakan pailit tidak diperbolehkan menjadi direksi atau komisaris perusahaan lain. Ketentuan ini adalah tidak benar karena kepailitan hanya berakibat hukum terhadap harta kekayaan saja dan tidak berakibat pada hak-hak sebjektif lain-lainnya.

10. Actio paulina dalam kepailitan

Actio Pauliana hanya dapat dilakukan dan dilaksanakan berdasarkan putusan Hakim Pengadilan. Demikian berarti sikap pembatalan perjanjian apapun juga alasannya, pihak manapun juga yang mengajukanya tetap menjadi wewenang Pengadilan. Dengan dijatuhkannya putusan yang membatalkan perjanjian atau tindakan yang merugikan kepentingan kreditor (khususnya harta kekayaan debitor), maka seluruh utang dan kebendaannya dikembalikan seperti semula. ${ }^{12}$

\section{Paksa Badan (Gijzeling)}

Debitor pailit bisa mendapat gijzeling (paksa badan) terutama ditujukkan apabila debitor pailit tidak kooperatif dalam pemberesan kepailitan.

\section{Ketentuan Pidana}

Debitor pailit dapat juga dikenakan ketentuan pidana yang mengacu kepada Kitab Undang-Undang Hukum Pidana (KUHP). Apabila pailit adalah PT maka dikenakan ketentuan pidana pada direksi dan/atau komisaris dan bahkan pemegang saham.

\section{Cakupan Harta Pailit}

Harta pailit juga meliputi segala sesuatu (harta) yang diperoleh selama kepailitan berlangsung. Pada hakikatnya kepailitan dimulai sejak putusan pailit diucapkan, hingga kepailitan berakhir. kepailitan merupakan suatu keadaan dimana seorang Debitor berhenti membayar utang-utangnya kepada Kreditor. Debitor itu dapat dinyatakan pailit oleh Pengadilan Niaga atas permohonan pernyataan pailit [44].

${ }^{12}$ Kartini Muljadi, Pedoman Menangani Perkara Kepailitan (RajaGrafindo Persada 2003). 
yang diajukan oleh Debitor Kreditor. Kemudian putusan atas permohonan pernyataan pailit, Pengadilan Niaga dapat memilih Kurator untuk melakukan pengurusan dan/ atau pemberesan terhadap harta Debitor pailit. Kurator lalu membagikan harta Debitor pailit kepada para Kreditor sesuai dengan piutangnya masing-masing.

\section{Saham Induk Perusahaan yang Pailit pada Anak Perusahaan}

Berdasarkan UU PT, induk perusahaan dan anak perusahaan secara yuridis adalah independen, tetapi secara ekonomi dipersatukan dengan induk perusahaan sebagai pemimpin pusat. Induk perusahaan dan anak perusahaan yang bisa disebut PT. Hubungan hukum antara perusahan induk dan perusahaan anak terjadi karena kepemilikan saham pada perusahaan anak oleh perusahaan induk, bahwa perusahaan induk menjadi pemegang saham utama perusahaan anak. Secara yuridis, perusahaan induk dan perusahaan anak dianggap sebagai subjek hukum independen yang memiliki hak untuk melakukan tindakan hukum mereka. Sebagai badan hukum independen, perusahaan induk atau perusahaan anak memiliki hak dan tanggung jawab sendiri. Selain itu, antara perusahaan induk dan perusahaan anak juga memiliki kekayaan terpisah dalam hal yuridis atau kepemilikan saham.

Perusahaan induk berperan sebagai pemegang saham perusahaan anak akan mempengaruhi dampak tertentu, termasuk:

1. Perusahaan induk memiliki kewenangan mengendalikan perusahaan anak melalui mekanisme rapat umum perusahaan anak.

2. Perusahaan induk memiliki tanggung jawab menempatkan arahan dan/atau anggota dewan komisaris dari perusahaan induk agar bekerja di tempat yang sama di perusahaan anak.

Keberadaan perusahaan induk sebagai penjamin dalam perjanjian antara perusahaan anak dan pihak ketiga dapat menimbulkan dampak hukum bagi perusahaan induk sebagai penjamin dari perusahaan anak dalam perjanjian pinjaman. Perusahaan induk sebagai penjamin dari perusahaan anak memiliki tanggung jawab membayar hutang debitor kepada kreditor jika debitor mengalami wanprestasi. Dengan demikian, perusahaan induk juga menjadi debitor dalam 
perjanjian penanggungan. Perusahaan induk yang bertindak sebagai penjamin perusahaan anak bertanggung jawab untuk membayar setelah hutang debitor pertama gagal bayar dan propertinya disita dan dilelang tetapi hasilnya terbukti tidak mampu membayar hutang, atau debitor gagal bayar tanpa properti. Selain itu, sebagai konsekuensi posisinya sebagai debitor, sebagai penjamin perusahaan anak, dapat dipailitkan oleh kreditor.

\section{Kesimpulan}

Perusahaan induk dapat menjamin hutang, dapat dimohonkan pailit atas dasar hutang yang diberikan kepada anak perusahaan karena pada dasarnya antara Perusahaan induk dan Perusahaan anak masing-masing memiliki hak dan kewajiban serta mempunyai harta kekayaan yang terpisah. Namun demikian apabila anak perusahaan berutang pada pihak lain dan Perusahaan induk menjamin utang tersebut, maka apabila Perusahaan anak tersebut wanprestasi, Perusahaan Induk dapat dimintai pertanggungjawabanya. Termasuk dapat dimohonkan pailit.

Apabila Perusahaan induk pailit maka yang menjadi harta pailit adalah semua harta kekayaan yang dimiliki oleh Perusahaan induk tersebut. Termasuk namun tidak terbatas saham kepemilikan pada anak perusahaan. Kepemilikan perusahaan saham induk pada anak perusahaan merupakan harta kekayaan dari Perusahaan induk, sehingga menjadi harta pailit apabila Perusahaan induk tersebut dinyatakan pailit.

\section{Daftar Bacaan}

\section{Buku}

Andy Hartanto, Hukum Jaminan dan Kepailitan (Laksbang Justitia 2015).

Kartini Muljadi, Pedoman Menangani Perkara Kepailitan (RajaGrafindo Persada 2003).

Munir Fuady, Hukum Perkreditan Kontemporer (Citra Aditya Bakti 2003).

Munir Fuady, Hukum Perusahaan Dalam Paradigma Hukum Bisnis (Citra Aditya Bakti 2008). 
M. Yahya Harahap, Hukum Perseroan Terbatas (Sinar Grafika 2013).

Rahayu Hartini, Penyelesaian Sengketa Kepailitan di Indonesia Dualisme Kewenangan Pengadilan Niaga \& Lembaga Arbitrase (Kencana 2009).

Sri Soedewi, Hukum Jaminan di Indonesia Pokok-Pokok Hukum Jaminan dan Jaminan Perorangan (Liberty 2011).

Sulistiowati, Tanggung Jawab Hukum Pada Perusahaan Grup Di Indonesia (Erlangga 2013).

Sulistiowati, Aspek Hukum Dan Realitas Bisnis Perusahaan Grup Di Indonesia (Erlangga 2010).

Sutarno, Aspek-aspek Hukum Perkreditan pada Bank (Alfabeta 2009).

HOW TO CITE: Andrew Ade Nugraha,'Kepailitan Terhadap Induk Perusahaan Yang Menjamin Utang Yang Diberikan Kepada Anak Perusahaan (Kajian Yuridis terhadap Putusan Nomor 05 / Pailit / 1998 / PN.Niaga / Jkt. Pst )' (2019) Vol. 2 No. 5 Jurist-Diction. 
--halaman ini sengaja dibiarkan kosong-- 